\title{
Ninety-three pictures and 108 questions for the elicitation of homophones
}

\author{
VICTOR S. FERREIRA and J. COOPER CUTTING \\ University of Illinois at Urbana-Champaign, Urbana, Illinois
}

\begin{abstract}
Homographs and homophones have interesting linguistic properties that make them useful in many experiments involving language. To assist researchers in the elicitation of homophones, this paper presents a set of 93 line-drawn pictures of objects with homophonic names and a set of 108 questions with homophonic answers. Statistics are also included for each picture and question: Picture statistics include name-agreement percentages, dominance, and frequency statistics of depicted referents, and picture-naming latencies both with and without study of the picture names. For questions, statistics include answer-agreement percentages, difficulty ratings, dominance, frequency statistics, and naming latencies for 60 of the most consistently answered questions.
\end{abstract}

Homophones are words such as (river-) bank and (money-) bank that have different meanings but have identical pronunciations. ${ }^{1}$ Homophonic stimuli have been widely used in psychological experiments, because homophone pairs are a sort of natural experiment (by controlling form while varying meaning) and they pose interesting processing and ambiguity resolution issues for psycholinguistic systems. Experiments employing homophones have been influential in the study of lexical access in word recognition (e.g., Simpson \& Krueger, 1991; Swinney, 1979; Tanenhaus, Leiman, \& Seidenberg, 1979), lexical frequency in language comprehension (e.g., McRae, Jared, \& Seidenberg, 1990), lexical frequency in language production (e.g., Dell, 1990; Griffin, 1995; Jescheniak \& Levelt, 1994), language acquisition (e.g., Doctor \& Coltheart, 1980), transsaccadic integration (Pollatsek, Lesch, Morris, \& Rayner, 1992), aging (Balota \& Duchek, 1991), psychological disorders (e.g., Clare, McKenna, Mortimer, \& Baddeley, 1993; Waters, Caplan, $\&$ Leonard, 1992) and have been used to control phonological factors (e.g., Wheeldon \& Monsell, 1994). In

This research was supported by National Science Foundation Grants SBR 93-19368 to Gary S. Dell and SBR 94-11627 to Kay Bock, and National Institutes of Health Grant R01-HD-21011 to Kay Bock. The first author was supported by a Natural Science and Engineering Research Council (Canada) Postgraduate Scholarship. The authors thank Kay Bock, Gary Dell, Peter Dixon, Zenzi Griffin, John Huitema, and an anonymous reviewer for helpful comments on early versions of this manuscript, Danielle Holthaus and Zenzi Griffin for help collecting data, Evan Pritchard for recording the question stimuli for presentation, and Gay Snodgrass for allowing us to reproduce the Snodgrass and Vanderwart (1980) pictures. Requests for reprints can be addressed to either author. V. Ferreira is now with the Department of Psychology, University of California, San Diego, La Jolla, CA 92093-0109 (e-mail: ferreira@psy.ucsd.edu); J. C. Cutting is with the Department of Psychology, University of South Carolina, Columbia, SC 29208 (cutting@ garnet.cla.sc.edu). To receive digital versions of the picture stimuli, a blank formatted floppy disk (PC or Macintosh) should be sent to either preceding address. The pictures (except for the Snodgrass \& Vanderwart, 1980 , pictures) can also be retrieved from http://dasparc.cogsci.uiuc.edu/ jcutting/homophones.html. short, homophones are very useful for studies involving language.

When designing experiments using homophones, an important methodological question concerns how homophones should be elicited from subjects. For experiments investigating homophone processing as an ambiguityresolution problem, the ambiguous word forms (e.g., "bank") can easily be used as stimuli. This report will make two alternative methods of homophone elicitation available to researchers. One method elicits homophone responses with picture stimuli; the other method uses questions. These methods are particularly useful when the use of ambiguous word-form stimuli may be ill suited for a particular investigation.

Eliciting homophones with pictures or questions can be especially useful for two reasons. First, eliciting homophones from meaning determines a particular meaning to elicit, in contrast to printed or spoken homophone stimuli. For example, if a subject says "bank" in response to reading bank, the response may be based on the sideof-the-river meaning, the financial institution meaning, neither, or both (although nonhomographic homophones like weak and week can be unambiguously presented by using printed word stimuli). Furthermore, investigations using printed stimuli have shown that under certain circumstances, reading homophones in a constraining sentence context (e.g., "I deposited my check in the bank") at least partially evokes multiple meanings of the homophone (e.g., Swinney, 1979, but see Simpson \& Krueger, 1991). Hence, to elicit a specific or individual homophone meaning, meaning-based methods such as picture naming or questioning must be used.

Second, eliciting homophones with pictures or questions is much like natural word production, and thus tasks with pictures or questions can reveal characteristics of the language-production system (Bock, 1996). This is in contrast to reading or repeating tasks, which involve a strong comprehension component, and are unlikely to involve the crucial formulation processes involved in production. 
Thus, for language production or production-related investigations, where natural production processes are at issue, or for investigations into language-disordered populations, where comprehension and production processes often dissociate, a more meaning-based methodology for eliciting homophones is necessary.

This report includes 93 line-drawn pictures of objects with homophonic (noun) names, and 108 questions, the answers to which are homophonic nouns. Whether pictures or questions should be preferred for a particular investigation will depend on the nature of that investigation, but the needs of a wide range of experiments should be accommodated using one method or the other.

Appendix A contains 93 pictures of objects with homophonic names. To assist researchers in choosing stimuli, the pictures are accompanied by statistical information about relevant properties of the pictures and their names. The appendix includes agreement of name information, dominance of meaning statistics (how dominant the depicted meaning is relative to other meanings of the homophone; Twilley, Dixon, Taylor, \& Clark, 1994), printed word frequency (Francis \& Kučera, 1982), and mean picture-naming latencies. Naming latencies were collected both without study and when subjects studied the picture stimuli with each intended name. For many experimental purposes, studying the picture names beforehand does not compromise the dependent measure, but does increase the range of pictures that can be productively used.

Presenting homophones as pictures permits an unambiguous homophone referent to be identified, and, being a production task, allows language-production issues to be investigated (Bock, 1996). There are drawbacks to using picture presentation, however. Objects in pictures are necessarily highly imageable, so any homophone that is abstract (e.g., deed, as in accomplishment) or difficult to picture (e.g., ball, as in formal dance) will be poorly elicited with a picture stimulus. As a consequence of this, it is difficult to construct a set of picturable homophone pairs. Of the 93 pictures included in this set, only 12 (6 pairs) consist of paired homophones.

For investigations that require two members of a homophonic set to be elicited, this report makes available a second method of presentation. Appendix $B$ includes 54 pairs of questions, the correct answers to which are homophones. Agreement, difficulty, dominance, and frequency statistics are included for all 54 questions, and response latencies are included for 30 of the most consistently answered question pairs.

Eliciting homophones by asking questions of subjects suffers because a question unfolds in time, and thus reaction-time statistics to questions are relatively noisy and difficult to interpret. (Note, though, that we attempted to design the questions so as to load critical information near the end of the question, so that subjects would not determine the correct answer too early during presentation.) However, questions are relatively easy to present and unambiguously determine a particular homophonic referent to be identified. Furthermore, the answers to questions do not need to be imageable (like pictures), so fewer restrictions apply to which homophones can be tested with this method of elicitation. For this reason, this report is able to include 108 questions that elicit 54 different pairs of homophones.

The methods used to collect agreement and naminglatency information are described in Study 1 for picture stimuli and in Study 2 for question stimuli. The Results section of each study includes frequency distributions that summarize the agreement statistics for the pictures and questions, means and standard errors, and a summary of the correlations among all the measures. Appendixes $A$ and $B$ include the actual picture and question stimuli, as well as average statistics for each of the measures collected for each stimulus.

\section{STUDY 1 \\ Pictures}

\section{Method}

\section{Subjects}

For the agreement statistics, 33 students enrolled in an introductory psychology class at the University of Illinois participated for class credit. The norming of these stimuli was part of a larger norming session. The naming latencies (with and without study of picture names) were collected in two other experimental sessions; 20 different speakers participated in each session. These 40 subjects were members of the University of Illinois community; some participated for class credit in introductory psychology, while others were paid for participation.

\section{Materials}

Of the 93 pictures, 49 were taken from the Snodgrass and Vanderwart (1980) set, 39 were drawn by the second author, 3 were taken from the Philadelphia Comprehension Battery (Saffran, Schwartz, Linebarger, Martin, \& Bochetto, 1988), and 2 were taken from clip-art libraries. The source of each picture is indicated in Appendix A.

\section{Procedure}

Agreement session. Subjects were given a stapled booklet containing the 93 pictures, 6 per page, with a numbered line under each picture. Subjects were instructed to write down the first one-word name that came to mind for each picture, to not skip any pictures, and to guess at pictures that they did not know. Subjects were free to complete these booklets at their own pace. All subjects received the stimuli in the same order. Pictures of homophone pairs (e.g., bat and bat ) appeared at least 23 pictures apart.

Naming session. Subjects sat in front of a Quadra 800 computer, with a 17-in. color monitor and an external speaker, or a Power Macintosh $7100 / 80$, with an audiovisual monitor. Voice responses were collected by a Shure unidirectional head-worn microphone. The experiment was implemented using the PsyScope experimental software (Cohen, MacWhinney, Flatt, \& Provost, 1993), and latencies were measured with a PsyScope millisecond timer. At the beginning of each trial, the subjects saw a fixation point (an asterisk) for $200 \mathrm{msec}$, followed by a $500-\mathrm{msec}$ delay. The picture was then presented and remained on the screen until the voice key registered a response (no time-out criterion was imposed). Subjects who did not study the picture names were asked to say as quickly as possible the first one-word name they felt described the picture; subjects who did study the picture names were asked to use the name that they had studied for each picture. 
Each subject named all 93 homophone picture stimuli. In the nonstudy session, the subjects named an additional 122 filler pictures; in the study session, the subjects named an additional 75 filler pictures (the number of fillers was reduced in the study session so that the subjects would have fewer pictures to study). All naming sessions began with 13 separate lead-in pictures. The 20 subjects in each session received different random orderings of the 215 and 168 homophone and filler pictures, although the same random orderings were used for the study and nonstudy sessions.

Prior to naming the pictures, subjects in the study session were shown each picture on the computer screen with its intended name printed, entirely in lowercase letters, below the picture. The subjects were asked to study the pictures and names long enough so that they could correctly name the pictures during the experiment. They pressed the space bar when they felt they had sufficiently studied the picture. The duration of study was recorded by the experimental software and is reported in Appendix A along with each picture. Nostudy subjects did not see the pictures and names before the naming-latency trials.

Dominance and frequency statistics. Dominance statistics were calculated on the basis of University of Alberta norms of relative meaning frequencies (Twilley et al., 1994), except for plug, the dominance of which was estimated on the basis of figures reported by Gilhooly and Logie (1980). ${ }^{2}$ In the University of Alberta norms, the subjects generated associates to printed homographs, and the number of responses associated with particular meanings of a homograph are summed. For our picture stimuli, we report from these norms the proportion of all responses for a particular homograph that were categorized as associates of our depicted meaning.

Frequency statistics are taken from Francis and Kučera (1982). This corpus reports the estimated frequency of the printed form of English words in occurrences per million, broken down by form class. These frequencies therefore do not discriminate among the meanings of a homophone (except when meanings can be fully distinguished by form class), but they do provide an indication of how commonly a word is used in the language. Also, the overall printed form frequency can be multiplied by the dominance of the meaning (from the Twilley et al., 1994, norms) to gain a rough estimate of the frequency of a particular meaning (Griffin, 1995). Comparison of the frequency estimate based on dominance to a more direct estimate of spoken frequency of particular meanings (Griffin, 1996) shows the dominance estimate to be a reasonable measure of meaning frequency.

\section{Results and Discussion}

\section{Agreement Statistics}

Agreement percentages were calculated by totalling the number of subjects who identified each picture with its intended name, and dividing by the total number of subjects (and multiplying by 100). Across all 93 pictures, the mean agreement percentage was 82.9 (standard error of 2.1). Figure 1 shows the distribution of agreement percentages of each picture. The figure shows that most pictures had quite high agreement percentages: Of the 93 pictures, 51 had agreement percentages over $89 \%$. Other pictures, however, had quite low agreement percentages, with the lowest percentage being at $15.2 \%$. All statistics reported in this Results section are reported for each individual picture in Appendix A.

\section{Naming and Study Latencies}

Mean naming latencies for the pictures were calculated first by removing any latency more than 2.5 standard de- viations above or below the overall mean for that picture or for that subject. Any observation where subjects did not use the intended name or where the voice key mistriggered was excluded from latency analysis (although correctly named trials where the voice key mistriggered are still considered correct in the number correct column in Appendix A, as were inflectionally incorrect items [e.g., plurals] or phrasal responses [e.g., "the ball"]). When subjects did not study the pictures and intended names, the mean naming latency across all pictures was $933 \mathrm{msec}$, with a standard error of $7.3 \mathrm{msec}$. With study, the mean naming latency was $901 \mathrm{msec}$ with a standard error of $12.6 \mathrm{msec}$. The distributions of the number of pictures correctly identified in the two study conditions are shown in Figure 1.

Outliers for study latencies were determined on the basis of the 2.5 standard deviation cutoff, as with the naming latencies. The mean study latency across all pictures was $1,162 \mathrm{msec}$, with a standard error of $23.2 \mathrm{msec}$. The mean study latencies are included with each picture in Appendix A.

\section{Dominance and Frequency Statistics}

Dominance statistics come from studies that measure the proportion of responses that are an associate of the depicted meaning of the homophone. The mean dominance of the 93 pictures is .62 , with a range of $.00-.98$. The set represents a wide range of dominances, although there are more high-dominance items than low-dominance ones (perhaps because subjects in the Twilley et al., 1994, study used imaging as a strategy for generating associates).

The printed frequencies of the names of the 93 pictures represent a wide range of frequencies, with a median frequency of 51 occurrences per million and a range of 2-906 occurrences per million. The dominance of the picture meaning and frequency of the picture name are reported for each picture in Appendix A.

\section{Correlations}

The correlations among the picture and name measures are shown in Table 1. Unsurprisingly, the behavioral measures (percent agreement, naming latencies, and number correct) all correlate reliably with one another, such that the agreement and number-correct measures increase together, and the latency measures decrease together with increasing agreement and number correct. These correlations suggest that general difficulty in picture naming can manifest both as increased naming times and as decreased number correct. Study-time measures also show a predictable pattern: As study time increases, so do naming latencies, while percent agreement and number correct decrease. This suggests that subjects study the more difficult to name pictures longer.

The only reliable correlations with the item measures (dominance and frequency) occur between the dominance of the picture meanings and the latency and number correct without study. As dominance increases, so does unstudied number correct, while unstudied naming latency 

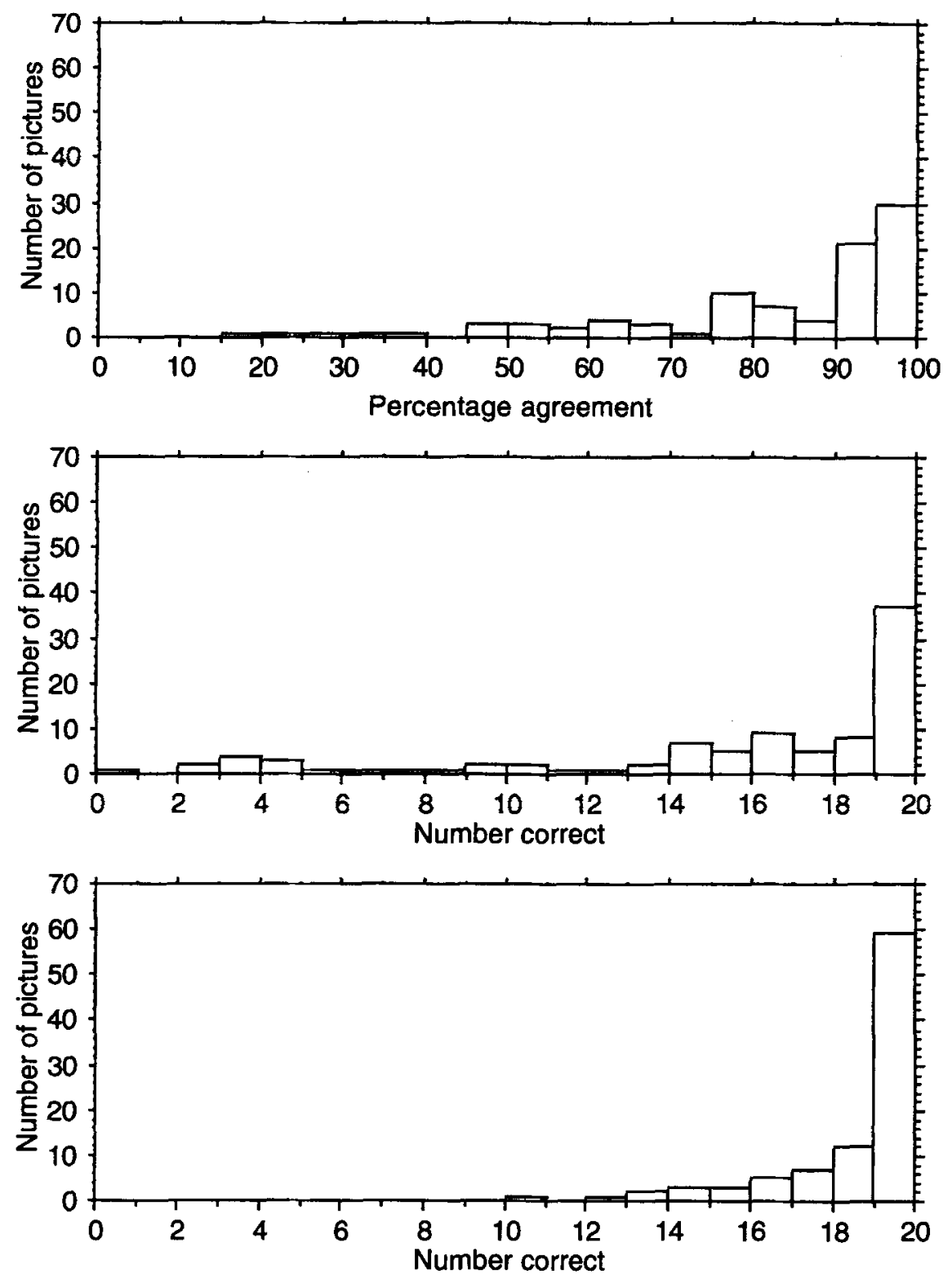

Figure 1. Distribution of name-agreement percentages (top panel) and number of pictures correctly named without study (middle panel) and with study (bottom panel) for all 93 pictures.

decreases. This suggests that at least with respect to unstudied picture naming, pictures of more dominant meanings are easier to name. However, given that dominance is ultimately a homophone-specific relative measure (it is the frequency of a meaning of a sound form, compared with other meanings of that sound form), why such correlations should appear (and why the correlations appear only without study) is unclear. A possible explanation is that the dominance measure itself is a reflection of an imagery-based strategy on the part of the subjects who provided those dominance measures, so that homophone meanings that are more imageable (and therefore easier to name as pictures) received higher dominance values.
STUDY 2

Questions

Method

\section{Subjects}

Agreement norms for the 54 pairs of questions were obtained from 40 University of Illinois undergraduates participating for class credit. Thirty-four different subjects, participating for class credit, provided the question-answering latencies for 30 of the most consistent question pairs.

\section{Materials}

All questions, reported in Appendix B, were designed by the authors. The wording of each question was chosen so as to select the intended word as uniquely as possible, and meaningful words were 
Table 1

Correlations Among Picture/Name Measures

\begin{tabular}{|c|c|c|c|c|c|c|c|}
\hline & \multicolumn{2}{|c|}{ Unstudied } & \multicolumn{3}{|c|}{ Studied } & \multirow[b]{2}{*}{ Dominance } & \multirow[b]{2}{*}{$\begin{array}{l}\log _{10} \\
\text { Freq. }\end{array}$} \\
\hline & Latency & $\begin{array}{l}\text { Number } \\
\text { Correct }\end{array}$ & Latency & $\begin{array}{l}\text { Number } \\
\text { Correct }\end{array}$ & $\begin{array}{l}\text { Study } \\
\text { Time }\end{array}$ & & \\
\hline Percent agreement & -.602 & .768 & -.551 & .573 & -.362 & .260 & -.026 \\
\hline $\begin{array}{l}\text { Unstudied } \\
\text { Latency } \\
\text { Number Correct }\end{array}$ & & -.641 & $\begin{array}{r}.675 \\
-.667\end{array}$ & $\begin{array}{r}-.458 \\
.705\end{array}$ & $\begin{array}{r}.595 \\
-.442\end{array}$ & $\begin{array}{r}-.420 \\
.291\end{array}$ & $\begin{array}{r}-.150 \\
.154\end{array}$ \\
\hline $\begin{array}{l}\text { Studied } \\
\text { Latency } \\
\text { Number Correct } \\
\text { Study Time }\end{array}$ & & & & -.662 & $\begin{array}{r}.547 \\
-.327\end{array}$ & $\begin{array}{r}-.188 \\
.105 \\
-.243\end{array}$ & $\begin{array}{r}-.103 \\
.233 \\
-.064\end{array}$ \\
\hline Dominance & & & & & & & .036 \\
\hline
\end{tabular}

Note-Boldface correlation values are reliable at the .01 level or better.

placed as close as possible to the end of the question so that the subjects would not ascertain the answer too early during the question. All stimuli were interrogative questions rather than fill-in-the-blank cloze items. For the collection of latencies, the questions were recorded on a Macintosh computer at a normal speaking rate, at a sampling rate of $22 \mathrm{kHz}$.

\section{Procedure}

Agreement statistics. Subjects were given a booklet of numbered questions. Each question was followed by a large and small blank. Subjects were asked to write in the large blank the first single-word answer that came to mind for each question. In the small blank, subjects rated how difficult the answer for that question was to think of, on a 1-7 scale (1 labeled Occurred immediately and 7 labeled Couldn't think of it). The subjects answered each question at their own pace. There were two different lists, each consisting of 54 questions, with only 1 question from each homophone pair on a particular list. Thus, the subjects did not give more than one meaning of a homophone as an answer, to make it less likely that they would realize that the questions were asking for homophones. Twenty subjects completed each list.

Question-answering latencies. The subjects sat in front of a Macintosh IIci computer with an 11-in. monochrome monitor, external speaker, PsyScope button box, and keyboard. Voice responses were collected by a Realistic highball microphone that sat on a stand directly in front of the monitor. The subjects began each trial by pressing the space bar; this was followed by a $500-\mathrm{msec}$ delay. The phrase "Get Ready" was then presented on the screen for $1,000 \mathrm{msec}$, and was immediately followed by auditory presentation of the question through the external speaker. After the offset of the question, a question mark appeared in the center of the screen, and remained there until the subject responded. As soon as the question mark disappeared, a sentence asking the subject to rate the difficulty of the question on a 1-7 scale (1 labeled easy, and 7, hard) appeared, along with a representation of the scale. This scale remained on the screen until the subject pressed an appropriate number key on the keyboard. A dash then appeared on the screen until the experimenter pressed a key on the button box, coding the accuracy of the subject's answer.

The subjects were instructed to answer each question with the first one-word answer that came to mind. They were asked to answer as quickly as possible after the question mark appeared. If the voice key registered a response prior to the question mark's being presented, the phrase "Too quick!" was printed in the center of the screen as the screen reversed colors.

The 60 questions for which latencies were collected were taken from the entire list of 108 questions for which agreement statistics were collected. Again, each question of a pair was answered by different subjects, so that the homophone status of the answers would not be readily apparent. The questions were presented in random order for each subject.

Dominance and frequency statistics. Dominance and frequency statistics were collected and calculated as in Study 1. In Study 2, two dominance statistics are reported. First, the absolute dominance, or the proportion of respondents in the Twilley et al. (1994) study who gave associates to the questioned meaning of a homophone, is reported. Second, the relative dominance, which measures the dominance of a meaning of a homophone relative to the other meaning of that homophone in this question set, is reported. Thus, the relative dominances of both items of a homophone pair will always add to 1 . The relative dominance was calculated by dividing the absolute dominance of one questioned meaning of the homophone by the sum of the absolute dominances of both questioned meanings of that homophone.

\section{Agreement Statistics}

Results and Discussion

An answer to a question was considered correct if a subject provided the intended answer, regardless of inflectional morphology (i.e., singular or plural). Agreement percentages were then calculated as in Study 1. The distribution of agreement percentages is shown in Figure 2 . The figure shows that agreement percentages were in general quite high; the mean agreement percentage across all questions was 79.0 (with a standard error of 2.16 ), and of the 108 questions, 57 had agreements over $90 \%$ and 70 had agreements over $80 \%$. Some questions had agreement percentages as low as $15 \%$. All statistics reported in this results section, along with the accompanying difficulty ratings when appropriate, are included with each question in Appendix B.

\section{Question-Answering Latencies}

Question-answering latency outliers were determined as in Study 1, as were errors and voice-key mistriggerings. After excluding outliers, the mean question-answering latency for the 60 measured questions was $662 \mathrm{msec}$ with a standard error of 22.7. As expected, the questions show a wide range of answering latencies; since questions unfold in time, the time to answer a question can be largely dependent on that question's wording. Nevertheless, answering-latency statistics can be useful for controlling particular aspects of question presentation, and 


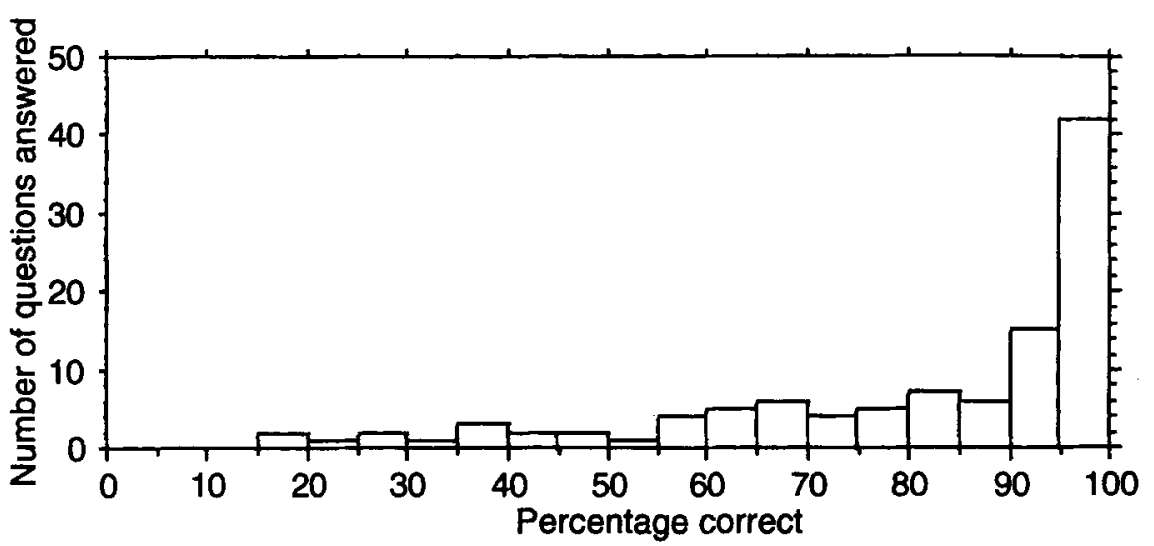

Figure 2. Distribution of answer-agreement percentages for all 108 questions.

so mean latencies (along with standard deviations, numbers correct, and mean difficulty ratings) are included in Appendix B.

\section{Dominance and Frequency Statistics}

The mean absolute dominance of the answers is .43, with a range of .00-.93. The median Francis and Kučera (1982) frequency is 46 occurrences per million, with a range of 6-506 occurrences per million. The absolute and relative dominances and the frequency of each question answer is presented for each question in Appendix B.

\section{Correlations}

The correlations among the question-and-answer measures are shown in Table 2 . As was the case with the picture measures, the correlations reveal that the behavioral measures are generally correlated: The proportion-correct measures increase together, while the latency- and difficulty-rating measures (generally) decrease together with increasing proportion correct. As with the pictures, these correlations suggest that the difficulty of the questions manifest in accuracy, answering time, and difficulty rating. Unsurprisingly, absolute and relative dominance are highly correlated. The only other correlation of note is between frequency and off-line difficulty rating, such that higher frequency words are reported as less difficult. Such a correlation should be interpreted cautiously, however, given that frequency did not correlate reliably with any other behavioral measure.

\section{CONCLUSIONS}

Due to their unique linguistic properties, ambiguous words like homographs and homophones have been used in hundreds of psycholinguistic experiments. In this report, we have provided researchers with the means necessary to elicit homographs and homophones with pictures and questions. Using pictures, researchers can have subjects name objects with homophonic names relatively reliably and with consistent naming latencies. Using questions, a wide variety of homophone answers can be elicited, so that issues involving pairs or sets of homophones can be addressed. Both sets can be used in production tasks, and thus permit investigation of production issues with homophones. For example, Cutting and Ferreira (1996) have used the homophone pictures to assess the effect of priming the nondepicted meaning of a homophone on production of the depicted meaning. In that experiment, subjects named homophone pictures while ignoring auditory distractor words that began $150 \mathrm{msec}$ prior to picture onset. The distractor words were either related to the depicted meaning of the picture (e.g., the distractor "game" with a

Table 2

Correlations Among Question/Answer Measures

\begin{tabular}{|c|c|c|c|c|c|c|c|}
\hline & \multirow{2}{*}{$\begin{array}{c}\text { Off Line } \\
\text { Difference } \\
\text { Rating }\end{array}$} & \multicolumn{3}{|c|}{ On Line } & \multirow[b]{2}{*}{$\begin{array}{l}\text { Abs. } \\
\text { Dom. }\end{array}$} & \multirow[b]{2}{*}{$\begin{array}{l}\text { Rel. } \\
\text { Dom. }\end{array}$} & \multirow[b]{2}{*}{$\begin{array}{l}\log _{10} \\
\text { Freq. }\end{array}$} \\
\hline & & Latency & $\begin{array}{l}\text { Number } \\
\text { Correct }\end{array}$ & $\begin{array}{c}\text { Difference } \\
\text { Rating }\end{array}$ & & & \\
\hline \multicolumn{8}{|l|}{ Off Line } \\
\hline Percent Correct & -.836 & -.401 & .392 & -.340 & .006 & .012 & .133 \\
\hline Difficulty rating & & .190 & -.242 & .353 & -.088 & -.106 & -.282 \\
\hline \multicolumn{8}{|l|}{ On Line } \\
\hline Latency & & & -.512 & .398 & -.061 & -.057 & -.003 \\
\hline Number Correct & & & & -.428 & .077 & .061 & .003 \\
\hline Difficulty rating & & & & & -.141 & -.159 & -.037 \\
\hline Abs. Dominance & & & & & & .962 & -.055 \\
\hline Rel. Dominance & & & & & & & .000 \\
\hline
\end{tabular}

Note-Boldface correlation values are reliable at the .01 level or better. 
picture of a toy ball) or the nondepicted meaning of the name of the picture (e.g., the distractor "dance" with a picture of a toy ball). The results showed that depicted meaning distractors slow picture naming (compared with an unrelated control condition), while nondepicted meaning distractors speeded picture naming, suggesting that lexical access during word production was nonstaged or "cascaded" (McClelland, 1979).

Furthermore, any experimental issue that requires elicitation of particular homophone meanings can achieve that goal with these stimuli. For example, a memory task could assess the effect of eliciting one meaning of a homophone on memory for the other meaning. ${ }^{3}$ Overall, the pictures and questions included here should provide researchers with the tools necessary to design experiments that broaden the range of empirical issues that can be addressed with homophones.

\section{REFERENCES}

Balota, D. A., \& DucheK, J. M. (1991). Semantic priming effects, lexical repetition effects, and contextual disambiguation effects in healthy aged individuals and individuals with senile dementia of the Alzheimer type. Brain \& Language, 40, 181-201.

Bock, K. (1996). Language production: Methods and methodologies. Psychonomic Bulletin \& Review, 3, 395-421.

Clare, L., McKenna, P. J., Mortimer, A. M., \& Baddeley, A. D. (1993). Memory in schizophrenia: What is impaired and what is preserved? Neuropsychologia, 31, 1225-1241.

Cohen, J., MacWhinney, B., Flatt, M., \& Provost, J. (1993). PsyScope: An interactive graphic system for designing and controlling experiments in the psychology laboratory using Macintosh computers. Behavior Research Methods, Instruments, \& Computers, 25, 257-271.

Cutting, J. C., \& Ferreira, V. S. (1996), Semantic and phonological information flow in the production lexicon. Manuscript submitted for publication.

DELL, G. S. (1990). Effects of frequency and vocabulary type on phonological speech errors. Language \& Cognitive Processes, 5, 313-349.

DOCTOR, E. A., \& COLThEART, M. (1980). Children's use of phonological encoding when reading for meaning. Memory \& Cognition, 8, 195-209.

Francis, W. N., \& KuČERA, H. (1982). Frequency analysis of English usage: Lexicon and grammar. Boston: Houghton-Mifflin.

GiLhOOLY, K. J., \& LoGIE, R. H. (1980). Meaning-dependent ratings of imagery, age of acquisition, familiarity, and concreteness for 387 ambiguous words. Behavior Research Methods \& Instrumentation, $12,428-450$.

GRIFFIN, Z. M. (1995). The locus of the word frequency effect in language production. Paper presented at the Sixty-Seventh Annual Meeting of the Midwestern Psychological Association, Chicago.
GRIFFIN, Z. M. (1997). Spoken word frequency ratings for homophones. Manuscript submitted for publication.

JESCHENIAK, J. D., \& LEVELT, W. J. M. (1994). Word frequency effects in speech production: Retrieval of syntactic information and of phonological form. Journal of Experimental Psychology: Learning, Memory, \& Cognition, 20, 824-843.

MCClELLAND, J. L. (1979). On the time relations of mental processes: An examination of systems of processes in cascade. Psychological Review, 86, 287-330.

McRae, K., JARED, D., \& Seidenberg, M. S. (1990). On the roles of frequency and lexical access in word naming. Journal of Memory \& Language, 29, 43-65.

Pollatsek, A., Lesch, M., Morris, R. K., \& Rayner, K. (1992). Phonological codes are used in integrating information across saccades in word identification and reading. Journal of Experimental Psychology: Human Perception \& Performance, 18, 148-162.

Saffran, E. M., Schwartz, M. F., Linebarger, M., Martin, N., \& Bochetto, P. (1988). Philadelphia comprehension battery. Unpublished test battery.

Simpson, G. B., \& Krueger, M. A. (1991). Selective access of homograph meanings in sentence context. Journal of Memory \& Language, 30, 627-643.

SnOdGRASS, J. G., \& VANDERWART, M. (1980). A standardized set of 260 pictures: Norms for name agreement, image agreement, familiarity, and visual complexity. Journal of Experimental Psychology: Human Learning \& Memory, 6, 174-215.

SWINNEY, D. A. (1979), Lexical access during sentence comprehension: (Re)consideration of context effects. Journal of Verbal Learning \& Verbal Behavior, 18, 645-659.

Tanenhaus, M. K., Leiman, J. M., \& Seidenberg, M. S. (1979). Evidence for multiple stages in the processing of ambiguous words in syntactic contexts. Journal of Verbal Learning \& Verbal Behavior, $18,427-440$.

Twilley, L. C., Dixon, P., TAylor, D., \& Clark, K. (1994). University of Alberta norms of relative meaning frequency for 566 homographs. Memory \& Cognition, 22, 111-126.

Waters, G. S., Caplan, D., \& Leonard, C. (1992). The role of phonology and reading comprehension: Implications of the effects of homophones on processing sentences with referentially dependent categories. Quarterly Journal of Experimental Psychology, 44A, 343-372.

WHEELDON, L. R., \& MONSELL, S. (1994). Inhibition of spoken word production by priming a semantic competitor. Journal of Memory \& Language, 33, 332-356.

\section{NOTES}

1. Strictly speaking, homophones can have different spellings (e.g., weak and week), but this set includes only homographic, as opposed to heterographic, homophones.

2. The items player, plug, and tank were not present in the Twilley et al. (1994) norms, and player and tank were not present in any published set of norms we could find. The latter two dominances have been left missing.

3. We thank Gary Dell for suggesting this idea. 
APPENDIX A

Pictures of Objects With Homophonic Names and Statistics

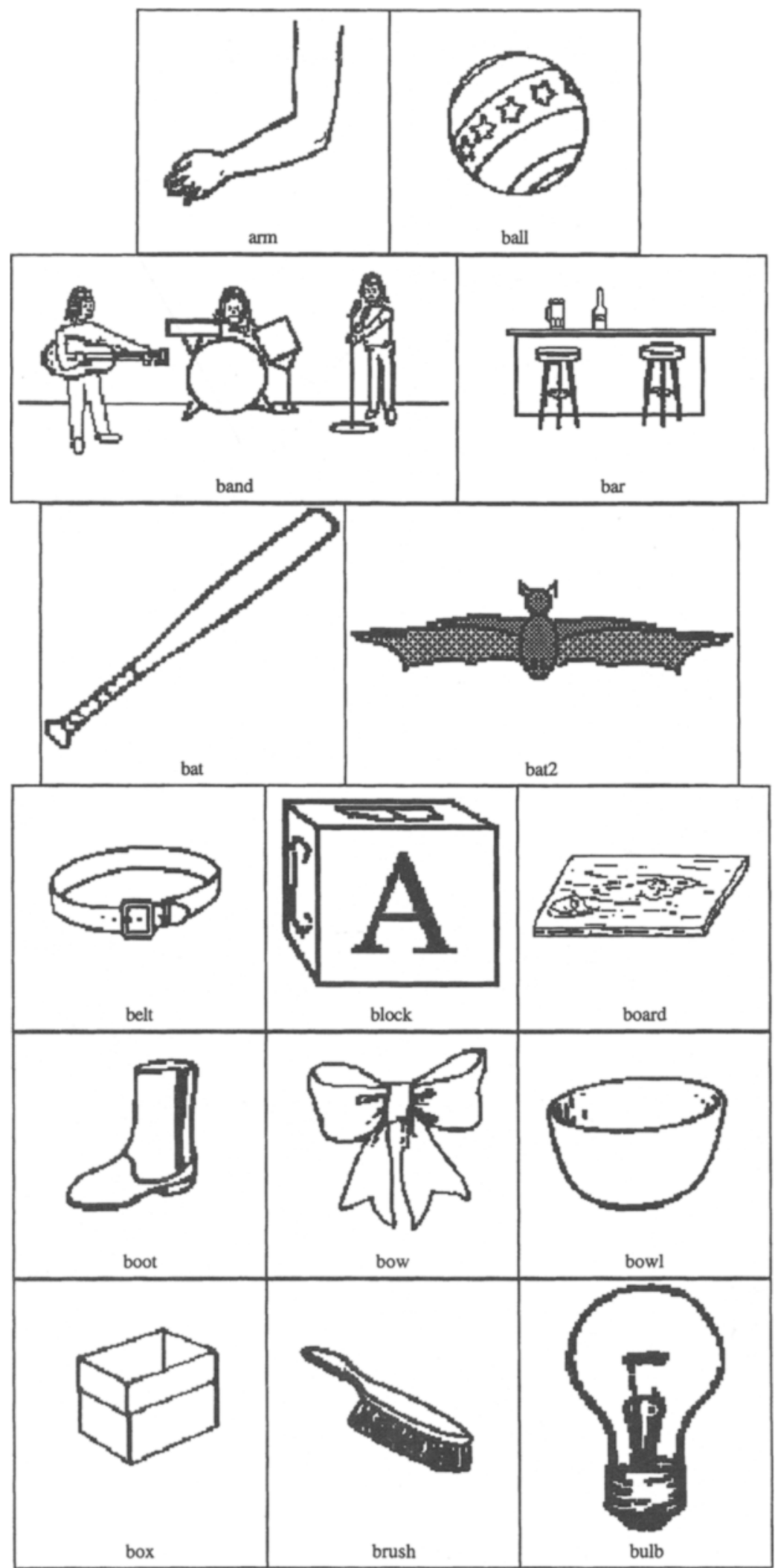


APPENDIX A (Continued)

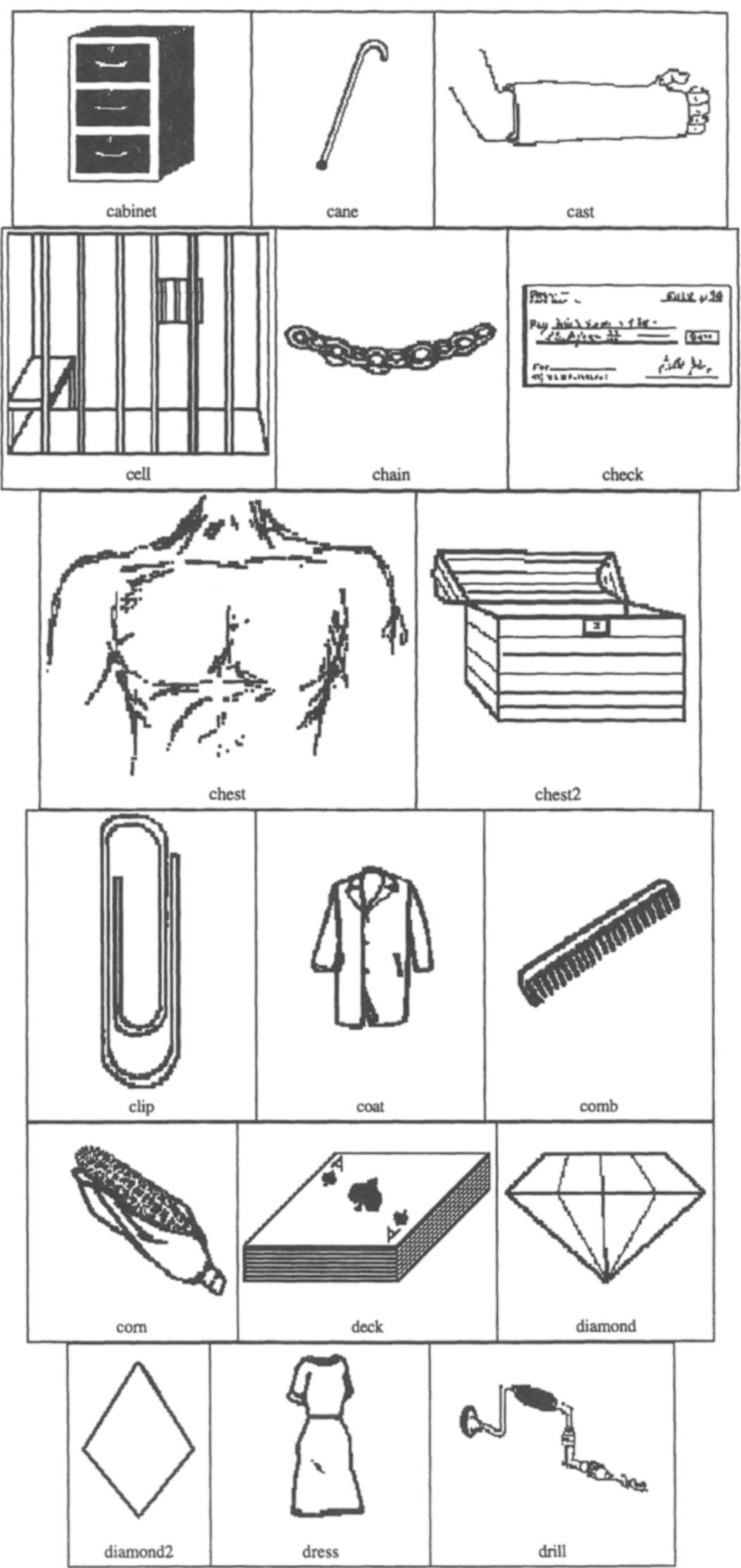


APPENDIX A (Continued)

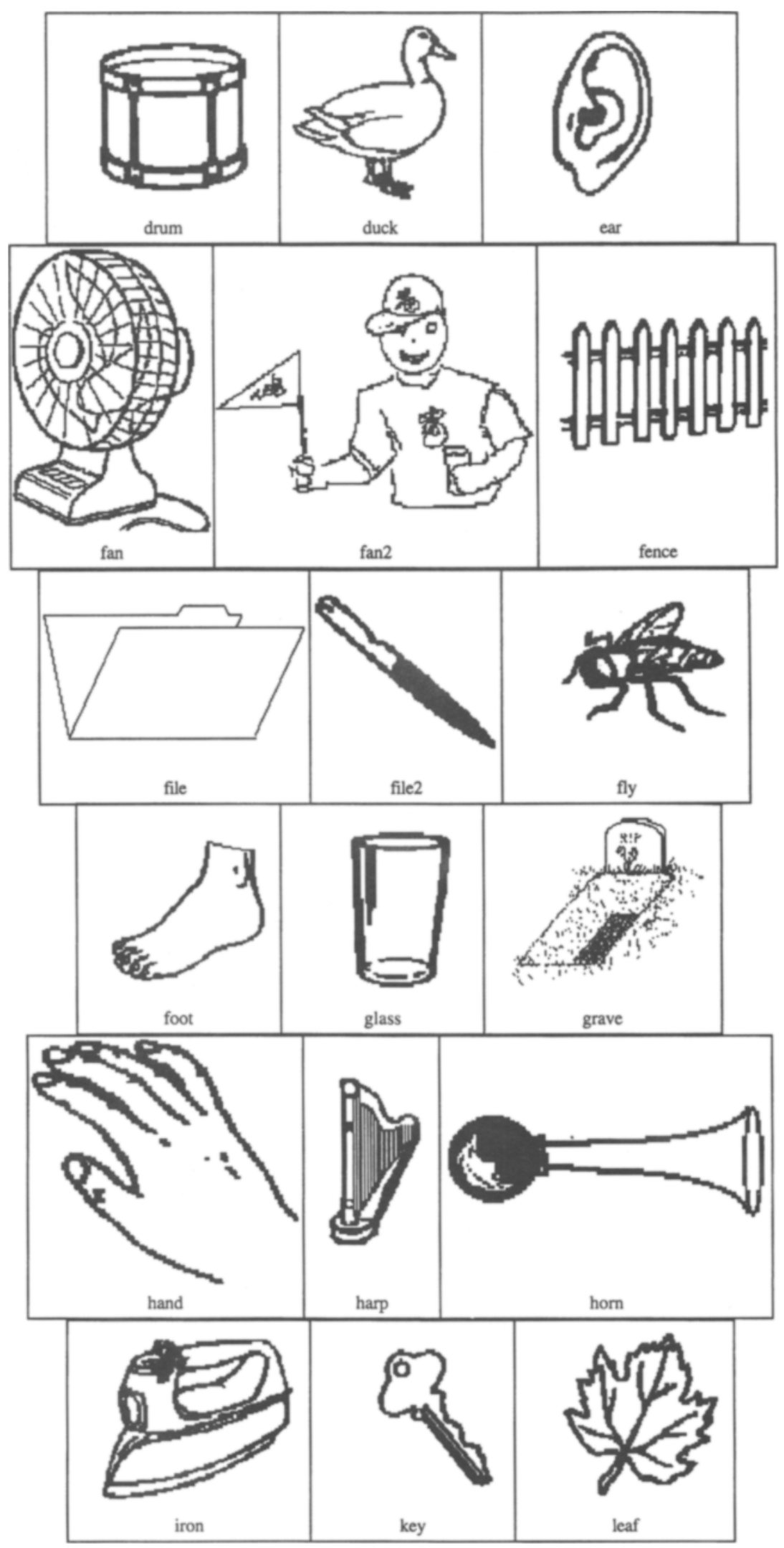


APPENDIX A (Continued)

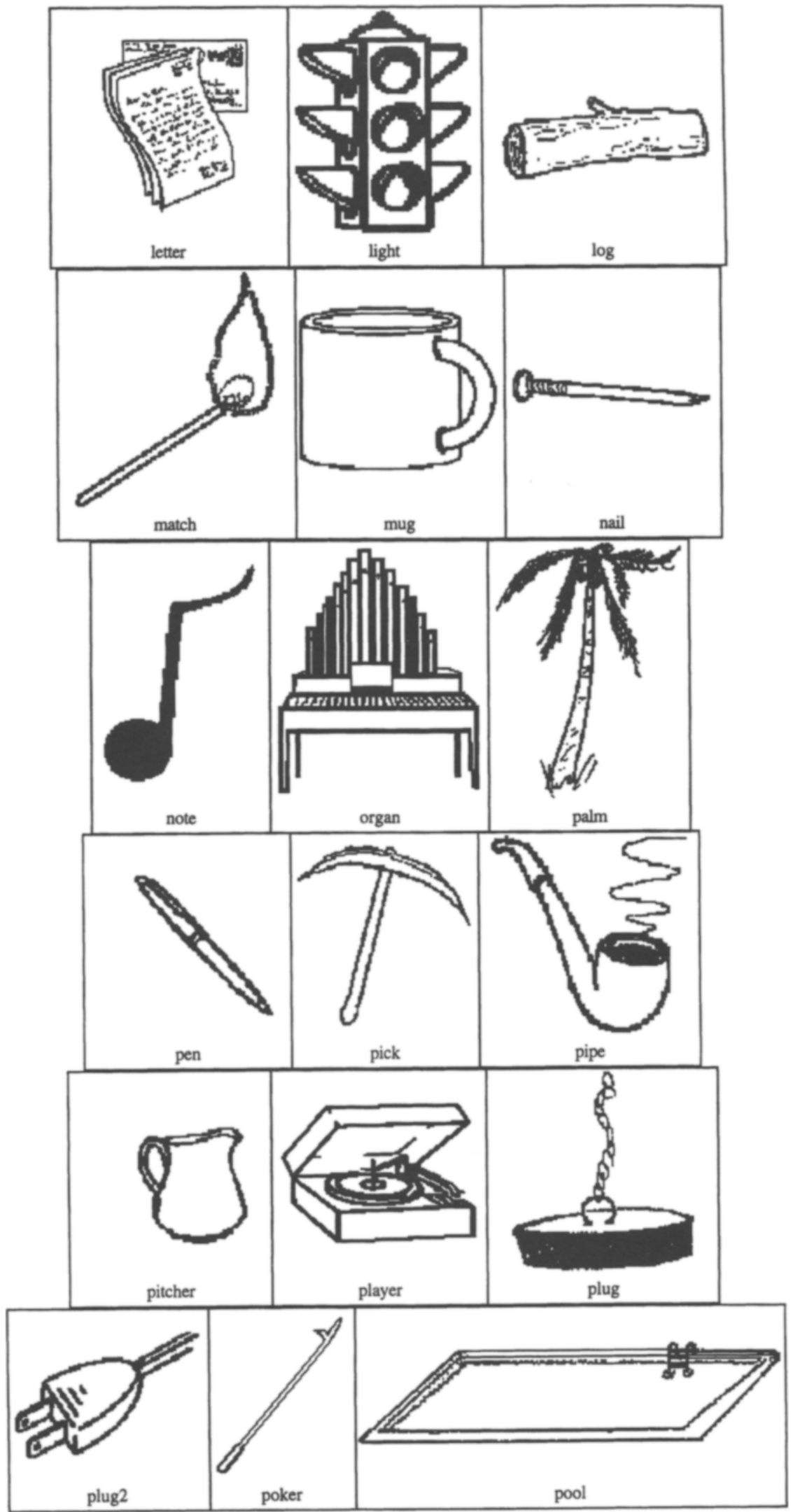


APPENDIX A (Continued)

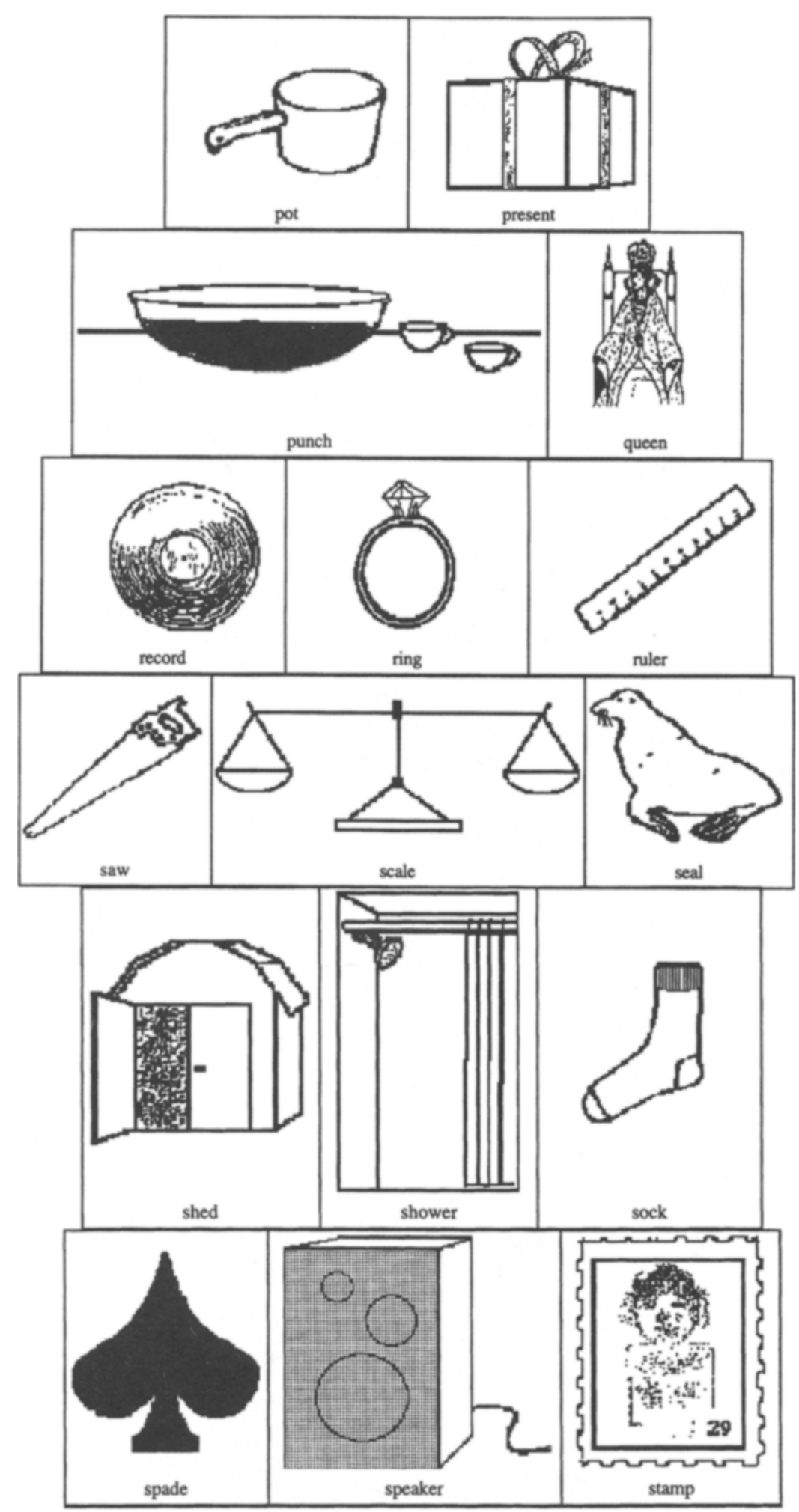




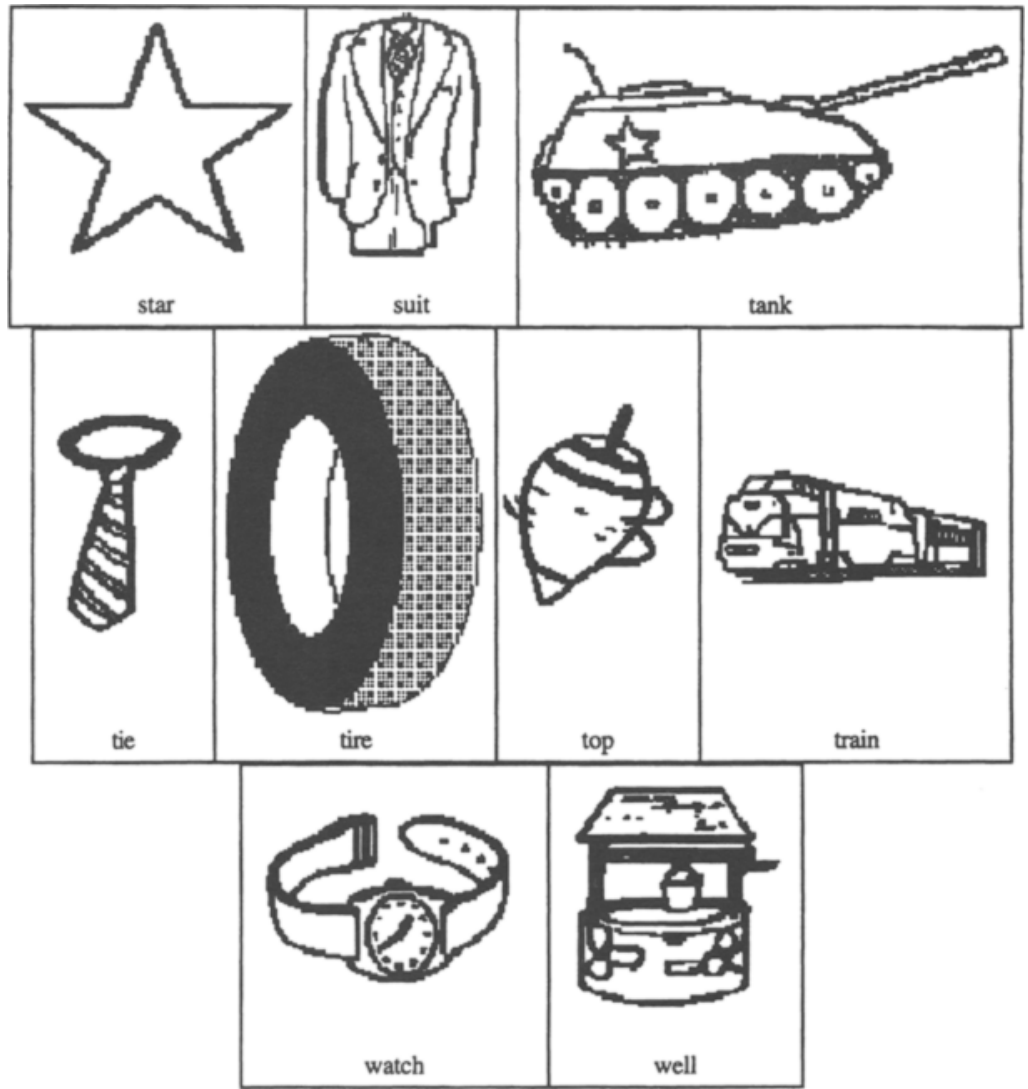

\begin{tabular}{|c|c|c|c|c|c|c|c|c|c|c|c|}
\hline \multirow{3}{*}{$\begin{array}{l}\text { Picture } \\
\text { Name }\end{array}$} & \multirow{3}{*}{$\begin{array}{c}\% \\
\text { Agreement }\end{array}$} & \multicolumn{3}{|c|}{ Unstudied } & \multicolumn{4}{|c|}{ Studied } & \multirow[b]{3}{*}{ Dominance } & \multirow[b]{3}{*}{ Freq. } & \multirow[b]{3}{*}{ Source } \\
\hline & & \multicolumn{2}{|c|}{ Latency } & \multirow{2}{*}{$\begin{array}{l}\text { Number } \\
\text { Correct }\end{array}$} & \multicolumn{2}{|c|}{ Latency } & \multirow{2}{*}{$\begin{array}{l}\text { Number } \\
\text { Correct }\end{array}$} & \multirow{2}{*}{$\begin{array}{c}\text { Study } \\
\text { Time }\end{array}$} & & & \\
\hline & & $M$ & $S D$ & & $M$ & $S D$ & & & & & \\
\hline arm & 78.8 & 732 & 64 & 20 & 749 & 107 & 19 & 1,008 & 0.91 & 278 & SV \\
\hline ball & 100.0 & 749 & 98 & 20 & 737 & 76 & 20 & 954 & 0.92 & 125 & SV \\
\hline band & 93.9 & 863 & 123 & 18 & 795 & 160 & 20 & 1,096 & 0.63 & 67 & $J C C$ \\
\hline bar & 84.8 & 1,128 & 215 & 20 & 899 & 119 & 20 & 1,221 & 0.79 & 133 & JCC \\
\hline bat & 100.0 & 713 & 72 & 20 & 719 & 114 & 20 & 920 & 0.34 & 41 & $\mathrm{JCC}$ \\
\hline bat 2 & 97.0 & 766 & 85 & 20 & 706 & 70 & 20 & 1,112 & 0.53 & 4! & SV \\
\hline belt & 90.9 & 900 & 244 & 16 & 821 & 185 & 20 & 1,941 & 0.85 & 39 & SV \\
\hline block & 75.8 & 939 & 111 & 17 & 904 & 228 & 20 & 1,188 & 0.45 & 118 & $\mathrm{JCC}$ \\
\hline board & 63.6 & 1,131 & 365 & 4 & 1,034 & 224 & 16 & 1,400 & 0.70 & 300 & $\mathrm{JCC}$ \\
\hline boot & 93.9 & 768 & 130 & 18 & 884 & 233 & 20 & 978 & 0.59 & 34 & SV \\
\hline bow & 90.9 & 920 & 325 & 18 & 807 & 194 & 16 & 1,207 & 0.26 & 26 & SV \\
\hline bowl & 100.0 & 935 & 248 & 17 & 903 & 253 & 19 & 1,116 & 0.64 & 26 & SV \\
\hline box & 100.0 & 899 & 255 & 20 & 869 & 228 & 20 & 1,094 & 0.75 & 84 & SV \\
\hline brush & 100.0 & 781 & 137 & 19 & 873 & 186 & 20 & 1,268 & 0.92 & 74 & SV \\
\hline bulb & 60.6 & 817 & 191 & 3 & 928 & 289 & 13 & 1,088 & 0.86 & 10 & SV \\
\hline cabinet & 63.6 & 1,075 & 302 & 4 & 1,109 & 273 & 12 & 1,523 & 0.79 & 22 & Clip \\
\hline cane & 93.9 & 826 & 83 & 20 & 896 & 221 & 19 & 1,145 & 0.69 & 13 & Phil \\
\hline cast & 97.0 & 1,073 & 97 & 15 & 932 & 147 & 20 & 1,209 & 0.34 & 54 & $\mathrm{JCC}$ \\
\hline cell & 48.5 & 1,197 & 186 & 3 & 1,016 & 161 & 19 & 1,451 & 0.48 & 146 & JCC \\
\hline chain & 84.8 & 984 & 200 & 16 & 846 & 128 & 19 & 1,047 & 0.78 & 60 & SV \\
\hline check & 100.0 & 954 & 122 & 19 & 860 & 150 & 20 & 1,087 & 0.31 & 141 & JCC \\
\hline chest & 66.7 & 1,006 & 145 & 20 & 851 & 247 & 20 & 1,171 & 0.27 & 57 & $\mathrm{JCC}$ \\
\hline chest 2 & 90.9 & 1,074 & 215 & 14 & 1,005 & 251 & 17 & 1,122 & 0.51 & 57 & $\mathrm{JCC}$ \\
\hline clip & 78.8 & 1,190 & 247 & 5 & 968 & 270 & 18 & 957 & 0.70 & 11 & $\mathrm{JCC}$ \\
\hline coat & 69.7 & 1,020 & 256 & 14 & 1,146 & 373 & 14 & 1,116 & 0.89 & 58 & SV \\
\hline comb & 100.0 & 801 & 152 & 20 & 788 & 144 & 19 & 1,069 & 0.98 & 11 & SV \\
\hline corn & 81.8 & 981 & 276 & 20 & 831 & 155 & 20 & 1,158 & 0.94 & 38 & SV \\
\hline
\end{tabular}


APPENDIX A (Continued)

\begin{tabular}{|c|c|c|c|c|c|c|c|c|c|c|c|}
\hline \multirow{3}{*}{$\begin{array}{l}\text { Picture } \\
\text { Name }\end{array}$} & \multirow{3}{*}{$\begin{array}{c}\% \\
\text { Agreement }\end{array}$} & \multicolumn{3}{|c|}{ Unstudied } & \multicolumn{4}{|c|}{ Studied } & \multirow[b]{3}{*}{ Dominance } & \multirow[b]{3}{*}{ Freq. } & \multirow[b]{3}{*}{ Source } \\
\hline & & \multicolumn{2}{|c|}{ Latency } & \multirow{2}{*}{$\begin{array}{l}\text { Number } \\
\text { Correct }\end{array}$} & \multicolumn{2}{|c|}{ Latency } & \multirow{2}{*}{$\begin{array}{l}\text { Number } \\
\text { Correct }\end{array}$} & Study & & & \\
\hline & & $M$ & $S D$ & & $M$ & $S D$ & & Time & & & \\
\hline deck & 33.3 & 870 & 134 & 2 & 969 & 197 & 17 & 958 & 0.19 & 30 & JCC \\
\hline diamond & 78.8 & 1,004 & 355 & 19 & 716 & 57 & 20 & 943 & 0.04 & 15 & JCC \\
\hline diamond2 & 84.8 & 1,128 & 292 & 15 & 857 & 206 & 20 & 1,165 & 0.89 & 15 & $\mathrm{JCC}$ \\
\hline dress & 90.9 & 840 & 184 & 20 & 870 & 190 & 20 & 1,099 & 0.88 & 130 & SV \\
\hline drill & 45.5 & 1,510 & 606 & 8 & 1,145 & 280 & 16 & 1,331 & 0.59 & 51 & Clip \\
\hline drum & 100.0 & 842 & 177 & 20 & 728 & 79 & 20 & 794 & 0.92 & 32 & SV \\
\hline duck & 93.9 & 799 & 151 & 16 & 1,035 & 330 & 18 & 1,161 & 0.81 & 21 & SV \\
\hline ear & 93.9 & 736 & 84 & 20 & 712 & 88 & 20 & 808 & 0.95 & 67 & SV \\
\hline fan & 97.0 & 832 & 136 & 20 & 758 & 87 & 20 & 968 & 0.75 & 47 & Phil \\
\hline $\operatorname{fan} 2$ & 75.8 & 1,335 & 346 & 10 & 1,012 & 224 & 20 & 1,646 & 0.19 & 47 & $\mathrm{JCC}$ \\
\hline fence & 93.9 & 822 & 186 & 19 & 778 & 105 & 20 & 1,060 & 0.83 & 50 & SV \\
\hline file & 27.3 & 1,133 & 430 & 6 & 940 & 238 & 16 & 1,175 & 0.72 & 146 & JCC \\
\hline file 2 & 15.2 & 1,635 & 41 & 3 & 1,078 & 293 & 14 & 1,500 & 0.19 & 146 & SV \\
\hline fly & 75.8 & 1,024 & 320 & 13 & 877 & 155 & 19 & 1,164 & 0.34 & 115 & SV \\
\hline foot & 93.9 & 775 & 139 & 20 & 776 & 136 & 20 & 818 & 0.93 & 363 & SV \\
\hline glass & 84.8 & 765 & 158 & 14 & 919 & 204 & 20 & 1,300 & 0.29 & 128 & SV \\
\hline grave & 100.0 & 961 & 239 & 17 & 880 & 148 & 19 & 1,208 & 0.88 & 39 & $\mathrm{JCC}$ \\
\hline hand & 100.0 & 739 & 92 & 19 & 694 & 102 & 20 & 967 & 0.93 & 769 & SV \\
\hline harp & 97.0 & 940 & 238 & 18 & 864 & 209 & 19 & 1,113 & 0.80 & 2 & SV \\
\hline horn & 97.0 & 1,011 & 255 & 20 & 840 & 118 & 20 & 1,081 & 0.77 & 33 & JCC \\
\hline iron & 100.0 & 806 & 121 & 19 & 797 & 196 & 20 & 1,067 & 0.47 & 57 & SV \\
\hline key & 97.0 & 732 & 85 & 20 & 770 & 127 & 20 & 986 & 0 & 104 & SV \\
\hline leaf & 100.0 & 770 & 177 & 20 & 786 & 152 & 19 & 1,027 & 9 & 34 & SV \\
\hline letter & 93.9 & 905 & 128 & 18 & 938 & 167 & 20 & 1,102 & 0.68 & 262 & SV \\
\hline light & 75.8 & 1,005 & 212 & 11 & 878 & 211 & 18 & 875 & 0.78 & 441 & SV \\
\hline $\log$ & 87.9 & 807 & 143 & 15 & 880 & 184 & 17 & 1,088 & 0.80 & 25 & $\mathrm{JCC}$ \\
\hline match & 78.8 & 1,040 & 279 & 16 & 1,032 & 327 & 20 & 1,194 & 0.58 & 101 & $\mathrm{JCC}$ \\
\hline mug & 75.8 & 891 & 159 & 4 & 1,099 & 349 & 14 & 1,071 & 0.84 & 3 & JCC \\
\hline nail & 100.0 & 894 & 204 & 16 & 887 & 200 & 16 & 1,096 & 0.58 & 32 & SV \\
\hline note & 90.9 & 954 & 253 & 18 & 778 & 169 & 20 & 1,035 & 0.10 & 291 & $\mathrm{JCC}$ \\
\hline organ & 90.9 & 1,085 & 327 & 13 & 834 & 143 & 18 & 1,159 & 0.47 & 26 & $\mathrm{JCC}$ \\
\hline palm & 24.2 & 1,337 & - & 2 & 843 & 130 & 17 & 1,250 & 0.27 & 32 & $\mathrm{JCC}$ \\
\hline pen & 100.0 & 772 & 112 & 20 & 825 & 120 & 20 & 949 & 0.91 & 23 & SV \\
\hline pick & 60.6 & 1,196 & 440 & 9 & 1,101 & 486 & 17 & 1,875 & 0.14 & 148 & $\mathrm{JCC}$ \\
\hline pipe & 97.0 & 872 & 125 & 19 & 764 & 101 & 20 & 1,081 & 0.51 & 32 & Phil \\
\hline pitcher & 87.9 & 1,064 & 255 & 17 & 1,040 & 304 & 15 & 1,497 & 0.49 & 29 & SV \\
\hline player & 45.5 & - & - & 0 & 1,039 & 210 & 15 & 1,361 & - & 54 & SV \\
\hline plug & 90.9 & 1,365 & 431 & 12 & 1,022 & 255 & 18 & 1,974 & 0.36 & 29 & SV \\
\hline plug2 & 39.4 & 933 & 130 & 19 & 829 & 155 & 19 & 1,177 & 0 & 29 & $\mathrm{JCC}$ \\
\hline poker & 57.6 & 1,668 & 404 & 3 & 1,127 & 282 & 10 & 1,409 & 0.09 & 6 & $\mathrm{JCC}$ \\
\hline pool & 100.0 & 1,024 & 168 & 15 & 888 & 161 & 18 & 1,266 & 0.73 & 135 & $\mathrm{JCC}$ \\
\hline pot & 57.6 & 1,079 & 290 & 10 & 1,056 & 268 & 15 & 1,185 & 0.70 & 37 & SV \\
\hline present & 54.5 & 1,024 & 241 & 14 & 1,046 & 299 & 17 & 1,320 & 0.53 & 503 & $\mathrm{JCC}$ \\
\hline punch & 72.7 & 1,545 & 416 & 7 & 1,030 & 285 & 18 & 1,549 & 0.23 & 8 & $\mathrm{JCC}$ \\
\hline queen & 66.7 & 1,124 & 219 & 17 & 927 & 131 & 19 & 1,130 & 0.90 & 51 & SV \\
\hline record & 81.8 & 1,078 & 408 & 16 & 1,058 & 285 & 19 & 1,149 & 0.84 & 288 & $\mathrm{JCC}$ \\
\hline ring & 97.0 & 845 & 184 & 20 & 878 & 288 & 17 & 899 & 0.63 & 84 & SV \\
\hline ruler & 100.0 & 841 & 174 & 20 & 841 & 238 & 18 & 1,179 & 0.75 & 13 & SV \\
\hline saw & 100.0 & 903 & 196 & 20 & 851 & 171 & 19 & 880 & 0.66 & 17 & SV \\
\hline scale & 51.5 & 1,232 & 458 & 14 & 1,082 & 341 & 18 & 1,207 & 0.77 & 66 & $\mathrm{JCC}$ \\
\hline seal & 100.0 & 957 & 149 & 15 & 961 & 182 & 19 & 1,002 & 0.50 & 37 & SV \\
\hline shed & 51.5 & 1,329 & 322 & 9 & 1,283 & 388 & 13 & 1,503 & 0.52 & 17 & $\mathrm{JCC}$ \\
\hline shower & 93.9 & 1,115 & 258 & 19 & 933 & 148 & 20 & 1,368 & 0.65 & 23 & JCC \\
\hline sock & 100.0 & 765 & 89 & 20 & 757 & 123 & 20 & 993 & 0.88 & 12 & SV \\
\hline spade & 84.8 & 1,369 & 382 & 14 & 884 & 159 & 20 & 1,257 & 0.27 & 8 & JCC \\
\hline speaker & 90.9 & 1,216 & 229 & 16 & 1,033 & 168 & 20 & 1,077 & 0.31 & 8 & $\mathrm{JCC}$ \\
\hline stamp & 90.9 & 878 & 91 & 16 & 926 & 192 & 20 & 1,267 & 0.74 & 67 & JCC \\
\hline star & 100.0 & 729 & 111 & 20 & 735 & 91 & 20 & 835 & 0.00 & 62 & SV \\
\hline suit & 78.8 & 1,145 & 346 & 14 & 1,012 & 169 & 18 & 1,039 & 0.83 & 95 & SV \\
\hline $\operatorname{tank}$ & 87.9 & 980 & 203 & 18 & 784 & 157 & 19 & 1,237 & * & 30 & $\mathrm{JCC}$ \\
\hline tie & 87.9 & 864 & 179 & 20 & 789 & 157 & 18 & 930 & 0.51 & 77 & SV \\
\hline tire & 93.9 & 980 & 285 & 18 & 907 & 242 & 18 & 1,230 & 0.87 & 77 & $\mathrm{JCC}$ \\
\hline
\end{tabular}


APPENDIX A (Continued)

\begin{tabular}{|c|c|c|c|c|c|c|c|c|c|c|c|}
\hline \multirow{3}{*}{$\begin{array}{l}\text { Picture } \\
\text { Name }\end{array}$} & \multirow{3}{*}{$\begin{array}{c}\% \\
\text { Agreement }\end{array}$} & \multicolumn{3}{|c|}{ Unstudied } & \multicolumn{4}{|c|}{ Studied } & \multirow[b]{3}{*}{ Dominance } & \multirow[b]{3}{*}{ Freq. } & \multirow[b]{3}{*}{ Source } \\
\hline & & \multicolumn{2}{|c|}{ Latency } & \multirow{2}{*}{$\begin{array}{l}\text { Number } \\
\text { Correct }\end{array}$} & \multicolumn{2}{|c|}{ Latency } & \multirow{2}{*}{$\begin{array}{l}\text { Number } \\
\text { Correct }\end{array}$} & \multirow{2}{*}{$\begin{array}{l}\text { Study } \\
\text { Time }\end{array}$} & & & \\
\hline & & $M$ & $S D$ & & $M$ & $S D$ & & & & & \\
\hline$\overline{\text { top }}$ & 93.9 & 1,041 & 251 & 16 & 995 & 277 & 19 & 950 & 0.04 & 221 & SV \\
\hline train & 93.9 & 1,068 & 161 & 19 & 845 & 154 & 19 & 1,330 & 0.82 & 216 & SV \\
\hline watch & 100.0 & 798 & 185 & 20 & 793 & 114 & 20 & 1,002 & 0.66 & 240 & SV \\
\hline well & 97.0 & 912 & 155 & 20 & 882 & 270 & 19 & 1,148 & 0.57 & 906 & SV \\
\hline
\end{tabular}

Note-Latencies and study times are measured in milliseconds, and frequencies are measured in occur rences per million. $J C C$ is picture drawn by the second author, Phil is picture from Saffran et al. (1988), and $S V$ is picture from "A standardized set of 260 pictures: Norms for name agreement, image agreement, familiarity, and visual complexity," by J. G. Snodgrass and M. Vanderwart, 1980, Journal of Experimental Psychology: Human Learning \& Memory, 6, pp. 197-204. Copyright 1980 by the American Psychological Association. Reprinted with permission.

APPENDIX B

Questions With Homophonic Answers and Statistics

\begin{tabular}{|c|c|c|c|c|c|c|c|c|c|}
\hline \multirow[b]{3}{*}{ Question } & \multirow[b]{3}{*}{ Answer } & \multicolumn{2}{|c|}{ Off Line } & \multicolumn{3}{|c|}{ On Line } & \multirow{3}{*}{$\begin{array}{c}\text { Abs. } \\
\text { Dominance }\end{array}$} & \multirow{3}{*}{$\begin{array}{c}\text { Rel. } \\
\text { Dominance }\end{array}$} & \multirow[b]{3}{*}{ Freq } \\
\hline & & \multirow{2}{*}{$\begin{array}{c}\text { Percent } \\
\text { Agreement }\end{array}$} & \multirow[b]{2}{*}{ Difficulty } & Latency & \multirow{2}{*}{$\begin{array}{l}\text { Number } \\
\text { Correct }\end{array}$} & \multirow[b]{2}{*}{ Difficulty } & & & \\
\hline & & & & $M S D$ & & & & & \\
\hline At what event did Cinderella lose her slipper? & ball & 100 & 1.4 & 579293 & 15 & 1.4 & 0.02 & 0.02 & 12 \\
\hline What do kids throw when they play catch? & & 90 & 1.8 & 523194 & 16 & 1.4 & 0.92 & 0.98 & \\
\hline $\begin{array}{l}\text { What do you call the place where you keep } \\
\text { your savings? }\end{array}$ & bank & 95 & 1.2 & 729375 & 6 & 2.3 & 0.54 & 1.00 & 117 \\
\hline $\begin{array}{l}\text { What do you call the land at the side } \\
\text { of a river? }\end{array}$ & & 85 & 2.1 & 607210 & 15 & 2.0 & 0.00 & 0.00 & \\
\hline What would you do a chin up on? & bar & 80 & 2.7 & 848397 & 14 & 2.2 & 0.07 & 0.08 & 133 \\
\hline $\begin{array}{l}\text { What type of establishment is the setting } \\
\text { for Cheers? }\end{array}$ & & 100 & 1.1 & 574183 & 16 & 1.7 & 0.79 & 0.92 & \\
\hline What do you call the sound made by dogs? & bark & 85 & 1.4 & 598239 & 14 & 1.3 & 0.68 & 0.72 & 14 \\
\hline What is the rough substance that coats trees? & & 95 & 1.3 & 662270 & 16 & 1.8 & 0.26 & 0.28 & \\
\hline With what would you hit a home run? & bat & 90 & 1.4 & $761 \quad 414$ & 14 & 1.3 & 0.53 & 0.61 & 41 \\
\hline $\begin{array}{l}\text { What animal sleeps in caves hanging } \\
\text { upside down? }\end{array}$ & & 95 & 1.4 & 417118 & 15 & 1.4 & 0.34 & 0.39 & \\
\hline $\begin{array}{l}\text { What do you call a concentrated stream } \\
\text { of light? }\end{array}$ & beam & 45 & 3.5 & & & & 0.61 & 0.73 & 39 \\
\hline What does a gymnast balance on? & & 95 & 1.6 & & & & 0.23 & 0.27 & \\
\hline What do you call a duck's beak? & bill & 60 & 4.1 & & & & 0.03 & 0.06 & 136 \\
\hline $\begin{array}{l}\text { What do you get from the phone company } \\
\text { once a month? }\end{array}$ & & 100 & 1.1 & & & & 0.50 & 0.94 & \\
\hline $\begin{array}{l}\text { What do you call the back of your leg below } \\
\text { your knee? }\end{array}$ & calf & 90 & 2.3 & 597231 & 8 & 1.9 & 0.11 & 0.12 & 17 \\
\hline What do you call a young cow? & & 90 & 1.6 & 667296 & 15 & 2.0 & 0.81 & 0.88 & \\
\hline $\begin{array}{l}\text { What do you call the mysteries that detectives } \\
\text { solve? }\end{array}$ & case & 30 & 4.3 & & & & 0.47 & 0.55 & 506 \\
\hline What do you carry a guitar in? & & 100 & 1.4 & & & & 0.38 & 0.45 & \\
\hline $\begin{array}{l}\text { What do you call the collection of players in } \\
\text { a movie? }\end{array}$ & cast & 40 & 3.8 & 832328 & 9 & 2.9 & 0.27 & 0.44 & 54 \\
\hline What does a doctor put on a broken leg? & & 80 & 1.7 & 677259 & 15 & 1.7 & 0.34 & 0.56 & \\
\hline What do you call a prisoner's quarters? & cell & 75 & 2.0 & & & & 0.48 & 0.55 & 146 \\
\hline $\begin{array}{l}\text { What biological structure are plants and } \\
\text { animals made of? }\end{array}$ & & 65 & 3.0 & & & & 0.40 & 0.45 & \\
\hline $\begin{array}{l}\text { On what part of his body did Superman sport } \\
\text { a big 'S'? }\end{array}$ & chest & 95 & 1.4 & 517212 & 11 & 1.5 & 0.51 & 0.65 & 57 \\
\hline $\begin{array}{l}\text { What container do pirates bury their } \\
\text { treasure in? }\end{array}$ & & 95 & 2.2 & 615231 & 14 & 1.7 & 0.27 & 0.35 & \\
\hline $\begin{array}{l}\text { In terms of population, what is the biggest } \\
\text { country in the world? }\end{array}$ & china & 65 & 2.7 & & & & 0.36 & 0.41 & \\
\hline What do you call fine porcelain dishware? & & 85 & 1.9 & & & & 0.51 & 0.59 & \\
\hline $\begin{array}{l}\text { What fur garment would you wear when it's } \\
\text { cold out? }\end{array}$ & coat & 50 & 2.2 & & & & 0.89 & 0.95 & 58 \\
\hline What do you call a layer of paint? & & 70 & 3.5 & & & & 0.05 & 0.05 & \\
\hline
\end{tabular}




\begin{tabular}{|c|c|c|c|c|c|c|c|c|c|c|}
\hline \multirow[b]{2}{*}{ Question } & \multirow[b]{2}{*}{ Answer } & \multicolumn{2}{|c|}{ Off Line } & \multicolumn{4}{|c|}{ On Line } & \multirow[b]{2}{*}{$\begin{array}{c}\text { Abs. } \\
\text { Dominance }\end{array}$} & \multirow[b]{2}{*}{$\begin{array}{c}\text { Rel. } \\
\text { Dominance }\end{array}$} & \multirow[b]{2}{*}{ Freq } \\
\hline & & $\begin{array}{c}\text { Percent } \\
\text { Agreement }\end{array}$ & Difficulty & y $\frac{\text { Late }}{M}$ & ency & $\begin{array}{l}\text { Number } \\
\text { Correct }\end{array}$ & Difficulty & & & \\
\hline $\begin{array}{l}\text { What do you call the number of balls and } \\
\text { strikes against a batter? }\end{array}$ & count & 60 & 3.1 & & & & & 0.71 & 0.77 & 96 \\
\hline What noble title could be applied to Dracula? & & 75 & 2.5 & & & & & 0.21 & 0.23 & \\
\hline What does a sailor swab? & deck & 35 & 4.6 & & & & & 0.63 & 0.77 & 30 \\
\hline What do fifty-two cards make up? & & 100 & 1.4 & & & & & 0.19 & 0.23 & \\
\hline $\begin{array}{l}\text { What good thing must a Boy Scout do } \\
\text { each day? }\end{array}$ & deed & 25 & 4.3 & & & & & 0.61 & 0.69 & 16 \\
\hline $\begin{array}{l}\text { What legal document do you get when you } \\
\text { buy a house? }\end{array}$ & & 20 & 4.2 & & & & & 0.28 & 0.31 & \\
\hline $\begin{array}{l}\text { What kind of stone does an engagement ring } \\
\text { usually have? }\end{array}$ & diamond & 100 & 1.6 & 509 & 232 & 14 & 1.5 & 0.89 & 0.96 & 15 \\
\hline What is the shape of a baseball infield? & & 100 & 1.51 & 1,035 & 311 & 13 & 2.5 & 0.04 & 0.04 & \\
\hline $\begin{array}{l}\text { What power tool do you use to make } \\
\text { holes with? }\end{array}$ & drill & 90 & 2.0 & & & & & 0.59 & 0.69 & 51 \\
\hline $\begin{array}{l}\text { What do you call an exercise that sergeants } \\
\text { lead their troops through? }\end{array}$ & & 70 & 3.0 & & & & & 0.26 & 0.31 & \\
\hline $\begin{array}{l}\text { What hangs from a ceiling and cools } \\
\text { you down? }\end{array}$ & fan & 95 & 1.8 & 467 & 264 & 15 & 1.7 & 0.75 & 0.80 & 47 \\
\hline What do you call an avid follower of a team? & & 95 & 2.6 & 864 & 227 & 13 & 2.1 & 0.19 & 0.20 & \\
\hline $\begin{array}{l}\text { On what part of your body do you wear } \\
\text { a shoe? }\end{array}$ & foot & 85 & 1.11 & 1,145 & 708 & 13 & 1.9 & 0.93 & 0.98 & 363 \\
\hline What distance does 12 inches make up? & & 100 & 1.1 & 582 & 243 & 13 & 1.5 & 0.02 & 0.02 & \\
\hline What do you call the fuel that runs your car? & gas & 80 & 1.1 & 885 & 579 & 5 & 1.6 & 0.80 & 0.96 & 111 \\
\hline $\begin{array}{l}\text { What is the state of a substance that is neither } \\
\text { solid nor liquid? }\end{array}$ & & 90 & 2.0 & 527 & 209 & 13 & 1.5 & 0.03 & 0.04 & \\
\hline $\begin{array}{l}\text { When driving, what do you use to audibly } \\
\text { warn someone? }\end{array}$ & horn & 90 & 1.5 & 747 & 422 & 11 & 1.7 & 0.77 & 0.82 & 33 \\
\hline What is on the head of a unicorn? & & 90 & 2.2 & 815 & 326 & 10 & 2.2 & 0.17 & 0.18 & \\
\hline $\begin{array}{l}\text { With what do you remove wrinkles } \\
\text { from clothes? }\end{array}$ & iron & 95 & 1.4 & 604 & 292 & 14 & 1.8 & 0.47 & 0.49 & 57 \\
\hline What are heavy frying pans made from? & & 60 & 2.2 & 884 & 344 & 8 & 3.5 & 0.49 & 0.51 & \\
\hline $\begin{array}{l}\text { Where do children sit when talking to } \\
\text { Santa Claus? }\end{array}$ & lap & 100 & 1.3 & 429 & 187 & 11 & 1.5 & 0.54 & 0.81 & 25 \\
\hline $\begin{array}{l}\text { What do you call the full distance } \\
\text { around a track? }\end{array}$ & & 60 & 3.2 & 746 & 424 & 11 & 2.1 & 0.13 & 0.19 & \\
\hline What does the alphabet consist of? & letter & 100 & 1.3 & 647 & 271 & 14 & 1.1 & 0.07 & 0.09 & 262 \\
\hline $\begin{array}{l}\text { What would you write to friends and send } \\
\text { in the mail? }\end{array}$ & & 90 & 1.2 & 544 & 136 & 14 & 1.6 & 0.68 & 0.91 & \\
\hline $\begin{array}{l}\text { What do you call the group of babies that } \\
\text { an animal has? }\end{array}$ & litter & 75 & 3.0 & & & & & 0.11 & 0.16 & 11 \\
\hline $\begin{array}{l}\text { What do you call the garbage along the side } \\
\text { of the road? }\end{array}$ & & 55 & 3.3 & & & & & 0.56 & 0.84 & \\
\hline $\begin{array}{l}\text { What do you call the place where they } \\
\text { make coins? }\end{array}$ & $\operatorname{mint}$ & 55 & 4.4 & & & & & 0.12 & 0.12 & 7 \\
\hline $\begin{array}{l}\text { What is the common flavor of after-dinner } \\
\text { chocolates? }\end{array}$ & & 95 & 1.9 & & & & & 0.85 & 0.88 & \\
\hline What grows on old cheese? & mold & 100 & 1.1 & & & & & 0.67 & 0.71 & 72 \\
\hline $\begin{array}{l}\text { What do you pour Jello into to give it } \\
\text { a shape? }\end{array}$ & & 65 & 1.6 & & & & & 0.27 & 0.29 & \\
\hline What do you call a single musical tone? & note & 80 & 1.8 & 900 & 404 & 8 & 2.3 & 0.10 & 0.11 & 291 \\
\hline $\begin{array}{l}\text { What would a schoolchild write and pass } \\
\text { around? }\end{array}$ & & 100 & 1.4 & 415 & 169 & 13 & 1.8 & 0.84 & 0.89 & \\
\hline $\begin{array}{l}\text { What piano-like instrument would you hear } \\
\text { at church? }\end{array}$ & organ & 95 & 1.7 & 539 & 265 & 16 & 1.4 & 0.47 & 0.48 & 26 \\
\hline $\begin{array}{l}\text { What is your heart, liver, or kidney an } \\
\text { example of? }\end{array}$ & & 100 & 1.1 & 586 & 255 & 16 & 2.4 & 0.50 & 0.52 & \\
\hline $\begin{array}{l}\text { What do you call the tall trees that line the } \\
\text { streets of Hawaii? }\end{array}$ & palm & 95 & 2.2 & 536 & 241 & 15 & 1.4 & 0.27 & 0.31 & 32 \\
\hline $\begin{array}{l}\text { What part of the hand does a } \\
\text { forture teller read? }\end{array}$ & & 100 & 1.1 & 843 & 458 & 7 & 2.3 & 0.59 & 0.69 & \\
\hline What is a pig kept in? & pen & 70 & 1.81 & 1,124 & 976 & 9 & 1.3 & 0.04 & 0.04 & 23 \\
\hline With what do you use to write in ink? & & 100 & 1.0 & 646 & 191 & 15 & 1.5 & 0.91 & 0.96 & \\
\hline What would you call a bottomless hole? & pit & 60 & 4.2 & & & & & 0.74 & 0.80 & 18 \\
\hline $\begin{array}{l}\text { What do you call the stone or seed of } \\
\text { a peach? }\end{array}$ & & 80 & 3.0 & & & & & 0.19 & 0.20 & \\
\hline $\begin{array}{l}\text { What glass container do you pour } \\
\text { water from? }\end{array}$ & pitcher & 85 & 2.2 & 560 & 231 & 12 & 1.4 & 0.48 & 0.49 & 29 \\
\hline
\end{tabular}


APPENDIX B (Continued)

\begin{tabular}{|c|c|c|c|c|c|c|c|c|c|c|}
\hline \multirow[b]{2}{*}{ Question } & \multirow[b]{2}{*}{ Answer } & \multicolumn{2}{|c|}{ Off Line } & \multicolumn{4}{|c|}{ On Line } & \multirow[b]{2}{*}{$\begin{array}{c}\text { Abs. } \\
\text { Dominance }\end{array}$} & \multirow[b]{2}{*}{$\begin{array}{c}\text { Rel. } \\
\text { Dominance }\end{array}$} & \multirow[b]{2}{*}{ Freq } \\
\hline & & $\begin{array}{c}\text { Percent } \\
\text { Agreement }\end{array}$ & Difficulty & Late & $\frac{\operatorname{ency}}{S D}$ & $\begin{array}{l}\text { Number } \\
\text { Correct }\end{array}$ & Difficulty & & & \\
\hline In baseball, who tries to throw strikes? & & 100 & 1.8 & 801 & 272 & 11 & 1.5 & 0.49 & 0.51 & \\
\hline In what game is a full house a good hand? & poker & 90 & 2.5 & & & & & 0.09 & 0.09 & 6 \\
\hline What do you call a sharp fireplace tool? & & 45 & 4.6 & & & & & 0.87 & 0.91 & \\
\hline $\begin{array}{l}\text { What do you call a gift received on your } \\
\text { birthday? }\end{array}$ & present & 95 & 2.0 & 538 & 161 & 13 & 1.7 & 0.53 & 0.69 & 503 \\
\hline $\begin{array}{l}\text { What do you call the time that is neither the } \\
\text { future nor the past? }\end{array}$ & & 95 & 1.2 & 360 & 157 & 17 & 1.6 & 0.24 & 0.31 & \\
\hline What fruit drink is served from a large bowl? & punch & 65 & 3.5 & 642 & 229 & 13 & 1.6 & 0.70 & 0.75 & 8 \\
\hline What do you call a hit with a closed fist? & & 95 & 2.0 & 463 & 160 & 14 & 1.7 & 0.23 & 0.25 & \\
\hline What do you call the black part of your eye? & pupil & 65 & 3.0 & & & & & 0.33 & 0.33 & 45 \\
\hline What do you call the student of a tutor? & & 15 & 3.5 & & & & & 0.67 & 0.67 & \\
\hline $\begin{array}{l}\text { What do you call someone who pretends } \\
\text { to be a doctor? }\end{array}$ & quack & 35 & 4.1 & & & & & 0.23 & 0.24 & 19 \\
\hline What is the sound made by a duck? & & 100 & 1.1 & & & & & 0.71 & 0.76 & \\
\hline What type of jewelry is worn on the finger? & ring & 100 & 1.1 & 583 & 251 & 15 & 1.3 & 0.63 & 0.68 & 84 \\
\hline $\begin{array}{l}\text { When someone calls, what sound does your } \\
\text { telephone make? }\end{array}$ & & 90 & 1.1 & 501 & 222 & 16 & 1.8 & 0.30 & 0.32 & \\
\hline $\begin{array}{l}\text { What do you stand on and weigh } \\
\text { yourself with? }\end{array}$ & scale & 95 & 1.6 & & & & & 0.77 & 0.96 & 64 \\
\hline $\begin{array}{l}\text { What part of a map tells you the inch-to-mile } \\
\text { conversion? }\end{array}$ & & 15 & 4.2 & & & & & 0.03 & 0.04 & \\
\hline $\begin{array}{l}\text { On medication, what do you call the plastic } \\
\text { used to prevent tampering? }\end{array}$ & seal & 35 & 3.9 & & & & & 0.40 & 0.44 & 37 \\
\hline $\begin{array}{l}\text { What animal claps and balances a ball } \\
\text { on its nose? }\end{array}$ & & 80 & 2.7 & & & & & 0.50 & 0.56 & \\
\hline $\begin{array}{l}\text { What is a group of words that starts with a } \\
\text { capital letter and ends with a period? }\end{array}$ & sentence & 75 & 2.7 & & & & & 0.72 & 0.77 & 56 \\
\hline $\begin{array}{l}\text { After a criminal is found guilty, what does } \\
\text { she or he receive? }\end{array}$ & & 90 & 2.2 & & & & & 0.21 & 0.23 & \\
\hline $\begin{array}{l}\text { In cards, what is the black suit that's } \\
\text { not clubs? }\end{array}$ & spade & 95 & 2.3 & & & & & 0.27 & 0.29 & 8 \\
\hline $\begin{array}{l}\text { What do you call the pointed shovel you } \\
\text { dig holes with? }\end{array}$ & & 55 & 4.9 & & & & & 0.66 & 0.71 & \\
\hline $\begin{array}{l}\text { What do you call a guest invited to talk } \\
\text { to an audience? }\end{array}$ & speaker & 90 & 1.8 & 677 & 226 & 8 & 2.6 & 0.58 & 0.65 & 67 \\
\hline $\begin{array}{l}\text { What do you call the part of the radio that } \\
\text { makes the sound? }\end{array}$ & & 90 & 1.7 & 863 & 365 & 13 & 2.3 & 0.31 & 0.35 & \\
\hline What season occurs after winter? & spring & 95 & 2.21 , &, 020 & 371 & 12 & 1.7 & 0.57 & 0.79 & 168 \\
\hline $\begin{array}{l}\text { What do you call the metal coil found } \\
\text { in mattresses? }\end{array}$ & & 90 & 2.5 & 589 & 196 & 14 & 2.1 & 0.15 & 0.21 & \\
\hline What are scarecrows usually made out of? & straw & 85 & 2.3 & 729 & 425 & 10 & 1.9 & 0.61 & 0.66 & 18 \\
\hline What do you drink a milkshake through? & & 95 & 1.2 & 567 & 139 & 15 & 1.7 & 0.31 & 0.34 & \\
\hline $\begin{array}{l}\text { What do you file against someone you wish } \\
\text { to take to court? }\end{array}$ & suit & 40 & 2.8 & & & & & 0.02 & 0.02 & 95 \\
\hline $\begin{array}{l}\text { What type of clothing would a man wear } \\
\text { to church? }\end{array}$ & & 80 & 2.0 & & & & & 0.83 & 0.98 & \\
\hline $\begin{array}{l}\text { Besides fleas, what does a collar protect } \\
\text { your dog from? }\end{array}$ & tick & 25 & 4.8 & & & & & 0.47 & 0.55 & 8 \\
\hline $\begin{array}{l}\text { What do you call the sounds that come } \\
\text { from a watch? }\end{array}$ & & 95 & 1.5 & & & & & 0.39 & 0.45 & \\
\hline What might a man wear around his neck? & tie & 55 & 1.7 & 800 & 613 & 12 & 1.1 & 0.51 & 0.96 & 77 \\
\hline $\begin{array}{l}\text { What do you call it when two teams have } \\
\text { the same score? }\end{array}$ & & 100 & 1.2 & 457 & 186 & 15 & 1.4 & 0.02 & 0.04 & \\
\hline What do you call the point of a felt pen? & tip & 75 & 3.5 & 613 & 395 & 11 & 2.0 & 0.46 & 0.61 & 40 \\
\hline $\begin{array}{l}\text { What do you give a waiter or waitress for } \\
\text { good service? }\end{array}$ & & 100 & 1.1 & 429 & 157 & 15 & 1.5 & 0.29 & 0.39 & \\
\hline Where in a car do you keep the spare tire? & trunk & 95 & 1.5 & 7003 & 313 & 14 & 1.7 & 0.66 & 0.84 & 13 \\
\hline What do you call the nose of an elephant? & & 95 & 1.5 & 621 & 182 & 15 & 2.1 & 0.13 & 0.16 & \\
\hline What distance does three feet make up? & yard & 70 & 2.4 & & & & & 0.29 & 0.32 & 100 \\
\hline What is the enclosed area behind a house? & & 65 & 1.5 & & & & & 0.63 & 0.68 & \\
\hline
\end{tabular}

Note-Latencies are measured in milliseconds, and frequencies in occurrences per million.

(Manuscript received November 28, 1995;

revision accepted for publication August 9, 1996.) 